\title{
Seabream Larval Physiology under Ocean Warming and Acidification
}

\author{
Marta S. Pimentel ${ }^{1, *}$, Filipa Faleiro ${ }^{1}$, Jorge Machado ${ }^{2} \mathbb{D}$, Pedro Pousão-Ferreira ${ }^{3}$ and \\ Rui Rosa ${ }^{1}$ (D) \\ 1 MARE-Marine and Environmental Sciences Centre, Laboratório Marítimo da Guia, \\ Faculdade de Ciências da Universidade de Lisboa, Av. Nossa Senhora do Cabo 939, 2750-374 Cascais, \\ Portugal; filipafaleiro@gmail.com (F.F.); rarosa@fc.ul.pt (R.R.) \\ 2 Instituto Ciências Biomédicas Abel Salazar, Universidade do Porto, Largo Prof. Abel Salazar 2, \\ 4099-003 Porto, Portugal; jmachado@icbas.up.pt \\ 3 Instituto Português do Mar e da Atmosfera, Av. 5 de Outubro s/n, 8700-305 Olhão, Portugal; \\ pedro.pousao@ipma.pt \\ * Correspondence: mcrsilva@fc.ul.pt; Tel.: +351-214-869-211
}

Received: 5 November 2019; Accepted: 10 December 2019; Published: 20 December 2019

\begin{abstract}
The vulnerability of early fish stages represents a critical bottleneck for fish recruitment; therefore, it is essential to understand how climate change affects their physiology for more sustainable management of fisheries. Here, we investigated the effects of warming $\left(\mathrm{OW} ;+4^{\circ} \mathrm{C}\right)$ and acidification $(\mathrm{OA} ; \Delta \mathrm{pH}=0.5)$ on the heart and oxygen consumption rates, metabolic enzymatic machinery-namely citrate synthase (CS), lactate dehydrogenase (LDH), and ß-hydroxyacyl CoA dehydrogenase (HOAD), of seabream (Sparus aurata) larvae (fifteen days after hatch). Oxygen consumption and heart rates showed a significant increase with rising temperature, but decreased with $p \mathrm{CO}_{2}$. Results revealed a significant increase of LDH activity with $\mathrm{OW}$ and a significant decrease of the aerobic potential (CS and HOAD activity) of larvae with OA. In contrast, under OA, the activity levels of the enzyme $\mathrm{LDH}$ and the LDH:CS ratio indicated an enhancement of anaerobic pathways. Although such a short-term metabolic strategy may eventually sustain the basic costs of maintenance, it might not be adequate under the future chronic ocean conditions. Given that the potential for adaptation to new forthcoming conditions is yet experimentally unaccounted for this species, future research is essential to accurately predict the physiological performance of this commercially important species under future ocean conditions.
\end{abstract}

Keywords: climate change; fish larvae; Sparus aurata; oxygen consumption; metabolism; aerobic potential; anaerobic potential

\section{Introduction}

Atmospheric $\mathrm{CO}_{2}$ concentrations are rising at unprecedented rates, and the continuous absorption of atmospheric $\mathrm{CO}_{2}$ by oceans is causing a decline in the oceans' $\mathrm{pH}$-a process known as ocean acidification [1]. If the rate of anthropogenic $\mathrm{CO}_{2}$ emissions continues to rise at the current pace, forecasts estimate an increase up to $1000 \mu \mathrm{atm}$ by the year 2100 [2], and above $2000 \mu \mathrm{atm}$ in some coastal areas [3]. Concurrently, the average temperature of oceans is also increasing, and additional warming (up to $3{ }^{\circ} \mathrm{C}$ ) is expected by the end of the century [4]. Such predicted changes manifest profound effects on marine organisms. Exposure to ocean acidification may narrow the thermal tolerance window and, consequently, intensify the impacts of increasing sea surface temperature on the biological processes of marine ectotherms, such as growth, calcification, behavior, and metabolism [5-10]. The effects of such environmental changes on fish populations are of great concern to society due to the socioeconomic value of marine fisheries and other ocean uses. 
The vulnerability of fish early life stages represent a critical bottleneck for fish population recruitment [11,12], and constitute the most vulnerable stages to ocean-climate-related stressors [13-19]. Their incomplete development, small size, lower swimming capabilities, lack of an effective ability to regulate their internal acid-base balance [20,21], and poor capacity to maintain their homeostasis (and compensate for extra and intracellular $\mathrm{pH}$ disturbances) increases fish early-stage vulnerability to such environmental changes. When fish are exposed to ocean acidification, $\mathrm{CO}_{2}$ enters by diffusion across the gill epithelia, the main organ for $\mathrm{pH}$ regulation, into fish tissues and fluids and, if not actively compensated by $\mathrm{HCO}_{3}{ }^{-}$accumulation and/or $\mathrm{H}^{+}$secretion, might result in extracellular acidosis [8]. Plasma pH changes may constrain the capacity of oxygen supply and delivery [22] and negatively affect the aerobic performance of marine fish [23]. Tissues may thereby become hypoxic, and the oxygen available to maintain cell functions or cover extra costs from activities beyond those required for basic maintenance is predicted to decrease [9]. In contrast, other studies have reported an increase in the aerobic performance [24,25], demonstrating interspecific variations to high $\mathrm{CO}_{2}$ levels.

Variations on the aerobic performance of organisms exposed to stressful conditions may reflect modifications of specific metabolic pathways that progressively lead to shifts in the energy production mode [9,26-34]. When the aerobic metabolism per se cannot satisfy energy demands, the anaerobic energy production pathway has to be activated [35]. Key metabolic enzymes such as citrate synthase (CS), lactate dehydrogenase (LDH), and B-hydroxyacyl CoA dehydrogenase (HOAD) are biochemical markers that can reflect these specific pathways and pathway shifts [36]. While CS is a key enzyme of the Krebs cycle, located in the mitochondrial matrix and a good indicator of aerobic metabolic potential [37], the cytosolic enzyme LDH is a terminal enzyme in the glycolytic pathway and a good indicator of anaerobic potential [38,39]. On the other hand, HOAD is used as an index of fatty acid oxidation and amino acid catabolism [40], and it is also a valuable indicator of the overall aerobic potential [37].

Within this context, here we investigated how future ocean warming $\left(+4{ }^{\circ} \mathrm{C}\right)$ and acidification $(\Delta \mathrm{pH}=0.5)$ might affect oxygen consumption and heart rates, as well as the metabolic enzymatic machinery (CS, LDH, and HOAD enzyme activities) during the early ontogeny of an active pelagic (and commercially important) fish, the seabream Sparus aurata. This species is an important coastal protandric hermaphrodite teleost dispersed across Mediterranean Sea and the Eastern Atlantic Ocean from the United Kingdom to Senegal, with preferred temperatures ranging from 12.1 to $21^{\circ} \mathrm{C}$. It has an increasing economic value within fisheries and aquaculture activities, and it can be found in both marine and brackish water environments such as coastal lagoons and estuarine areas, particularly during the initial stages of its life cycle. Understanding how this species will cope with predicted future environmental scenarios may provide valuable information on future stock population conditions [41]. We here hypothesized that the metabolic performance and the energy production mode of the early stages of this species might shift to an anaerobic mode of energy production when exposed to future ocean warming and acidification.

\section{Results}

\subsection{Oxygen Consumption and Routine Heart Rates}

After the acclimation period, both warming and high $\mathrm{CO}_{2}$-acidification caused significant changes in the metabolic rates of seabream larvae (Figure 1, GLM analysis described in Table 1, Gamma family, $p<0.001$ ). Oxygen consumption rates increased $23.55 \%$ with warming under normocapnia, and $21.52 \%$ under high $\mathrm{CO}_{2}$ conditions. On the other hand, acidification caused a significant decrease within both temperature treatments. This decrease was higher under warming conditions, decreasing from $36.78 \pm$ 2.01 to $28.79 \pm 1.86 \mu \mathrm{mol} \mathrm{O}_{2} \mathrm{~h}^{-1} \mathrm{~g}^{-1}$. No significant interaction was observed between these factors (GLM analysis described in Table 1, Gamma family, $p>0.05$ ). 
Table 1. Results of the statistical models applied for analysis of ocean warming and acidification effects in the early stages of Sparus aurata. Codes: ${ }^{* * *}$ when $p$-value $<0$; ${ }^{* *}$ when $p$-value $<0.001$.

\begin{tabular}{|c|c|c|c|c|c|c|c|}
\hline & Model & Terms & Estimate & Std. Error & $t$ value & $\operatorname{Pr}(>|t|)$ & \\
\hline \multirow{3}{*}{$\begin{array}{l}\text { Oxygen } \\
\text { Consumption } \\
\text { rate }\end{array}$} & GLM, family = & Intercept & 0.0338 & 0.00069 & 49.401 & $<2 \times 10^{-16}$ & $* * *$ \\
\hline & Gamma AIC = & Temperature & -0.0068 & 0.00079 & -8.678 & $4.98 \times 10^{-10}$ & $* * *$ \\
\hline & 159.097 & $\mathrm{pH}$ & 0.0079 & 0.00079 & 10.065 & $1.38 \times 10^{-11}$ & $* * *$ \\
\hline \multirow{3}{*}{ Heart rates } & GLM, family = & Intercept & 98.75 & 3.080 & 32.060 & $<2 \times 10^{-16}$ & $* * *$ \\
\hline & Gaussian AIC & Temperature & 29.00 & 4.356 & 6.657 & $3.64 \times 10^{-8}$ & $* * *$ \\
\hline & $=368.672$ & $\mathrm{pH}$ & -24.42 & 4.356 & -5.605 & $1.28 \times 10^{-6}$ & $* * *$ \\
\hline \multirow{3}{*}{ CS activity } & GLM, family = & Intercept & 1.9027 & 0.1121 & 15.678 & $7.68 \times 10^{-8}$ & $* * *$ \\
\hline & Gaussian AIC & Temperature & -0.4852 & 0.1401 & -3.462 & 0.30063 & \\
\hline & $=4.623$ & $\mathrm{pH}$ & 0.1539 & 0.1401 & 1.098 & 0.00714 & $* *$ \\
\hline \multirow{3}{*}{ LDH activity } & GLM, family = & Intercept & 2.1260 & 0.1371 & 15.511 & $8.43 \times 10^{-8}$ & $* * *$ \\
\hline & Gaussian AIC & Temperature & 0.6013 & 0.1583 & 3.799 & 0.00422 & $* *$ \\
\hline & $=7.542$ & $\mathrm{pH}$ & 1.5380 & 0.1583 & 9.718 & $4.54 \times 10^{-6}$ & $* * *$ \\
\hline \multirow{3}{*}{$\begin{array}{l}\text { HOAD } \\
\text { activity }\end{array}$} & GLM, family = & Intercept & 8.9219 & 0.5015 & 17.792 & $2.54 \times 10^{-8}$ & $* * *$ \\
\hline & Gaussian AIC & Temperature & 1.7513 & 0.5709 & 3.024 & 0.1437 & \\
\hline & $=38.672$ & $\mathrm{pH}$ & -2.2089 & 0.5709 & -3.815 & 0.00412 & $* *$ \\
\hline \multirow{3}{*}{$\begin{array}{l}\mathrm{LDH} / \mathrm{CS} \\
\text { ratio }\end{array}$} & GLM, family = & Intercept & 1.1267 & 0.2020 & 5.577 & 0.00344 & $* * *$ \\
\hline & Gaussian AIC & Temperature & 0.2237 & 0.2333 & 0.959 & 0.362656 & \\
\hline & $=16.023$ & $\mathrm{pH}$ & 1.4555 & 0.2333 & 6.239 & 0.000152 & $* * *$ \\
\hline
\end{tabular}

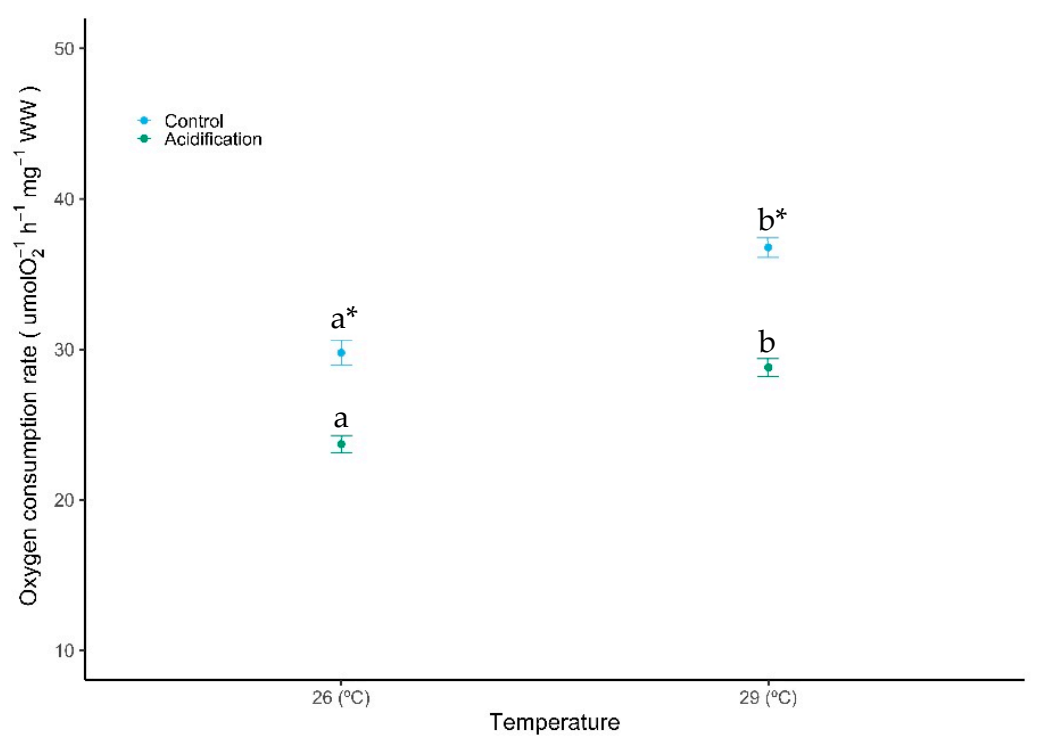

Figure 1. Impacts of ocean warming and acidification on the oxygen consumption rates (OCR) of Sparus aurata fish larvae. Values are given as mean $\pm \operatorname{SD}(n=9)$. Different letters $(a, b)$ represent significant differences between the temperature treatments and asterisks $\left(^{*}\right)$ represent significant differences between $\mathrm{CO}_{2}$ treatments $(p<0.001)$.

Routine heart rates of $S$. aurata were also significantly affected by high temperature and $\mathrm{CO}_{2}$ (Figure 2, GLM analysis described in Table 1, Gaussian family, $p<0.001$ ), increasing with temperature, but decreasing with high $p \mathrm{CO}_{2}$. The lowest heart rate $(74.33 \pm 6.15$ beats per minute) was observed under acidification, while the highest value (127.75 \pm 9.92 beats per minute) was reached under warming. When exposed to acidification, the heart rates of fish larvae decreased $24.73 \%$ and $13.69 \%$ under control and warming temperatures, respectively. No significant interaction was observed between these factors (GLM analysis described in Table 1, Gaussian family, $p>0.05$ ). 


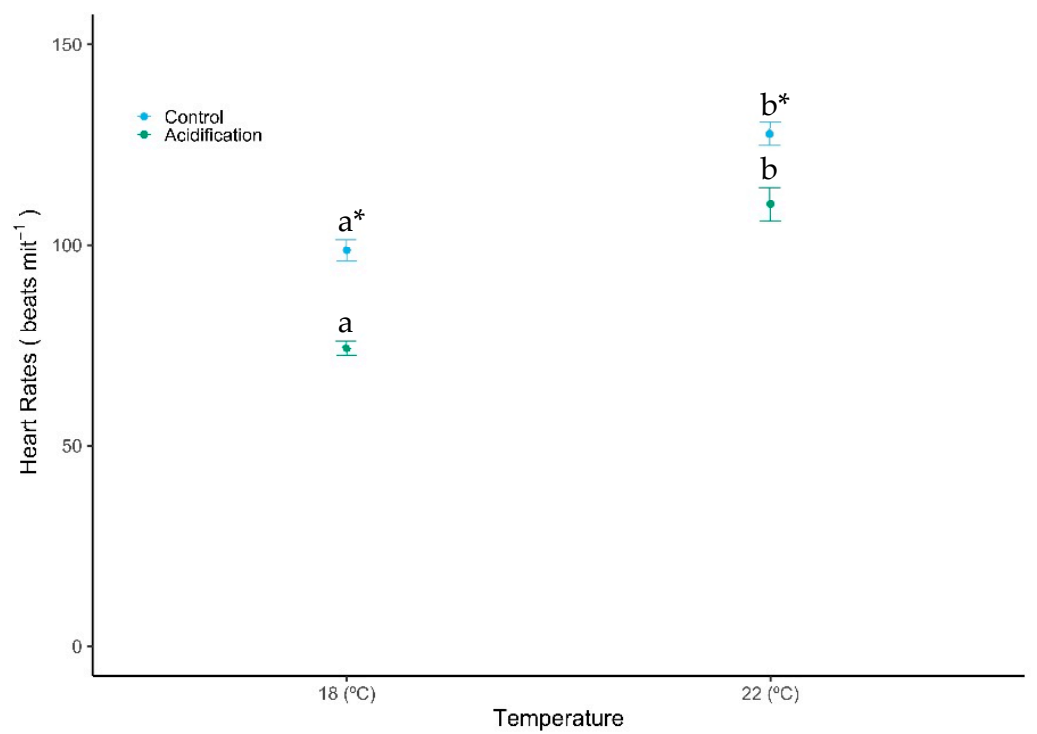

Figure 2. Impact of ocean warming and acidification on the routine heart rates of Sparus aurata fish larvae. Values are given as mean $\pm \operatorname{SD}(n=12)$. Different letters $(a, b)$ represent significant differences between the temperature treatments and asterisks $\left(^{*}\right)$ represent significant differences between $\mathrm{CO}_{2}$ treatments $(p<0.001)$.

\subsection{Enzyme Activity}

Exposure to ocean warming prompted significant changes in the metabolic enzymes of S. aurata. Citrate synthase (CS) activity of seabream larvae was not significantly affected by temperature (Figure 3, GLM analysis described in Table 1, Gaussian family, $p>0.05$ ), but acidification was revealed to cause a significant decrease in aerobic potential, i.e., CS activity (Figure 3, GLM analysis described in Table 1, Gaussian family, $p<0.01$ ). CS activity decreased with increasing $\mathrm{CO}_{2}$ from $1.86 \pm 0.41$ to $1.45 \pm 0.04 \mathrm{U} \mathrm{mg} \mathrm{protein}^{-1}$ under controlled temperature, and from $2.1 \pm 0.2$ to $1.5 \pm 0.3 \mathrm{U} \mathrm{mg}$ protein $^{-1}$ under warming. No significant interaction was observed between these factors (GLM analysis described in Table 1, Gaussian family, $p>0.05$ ).

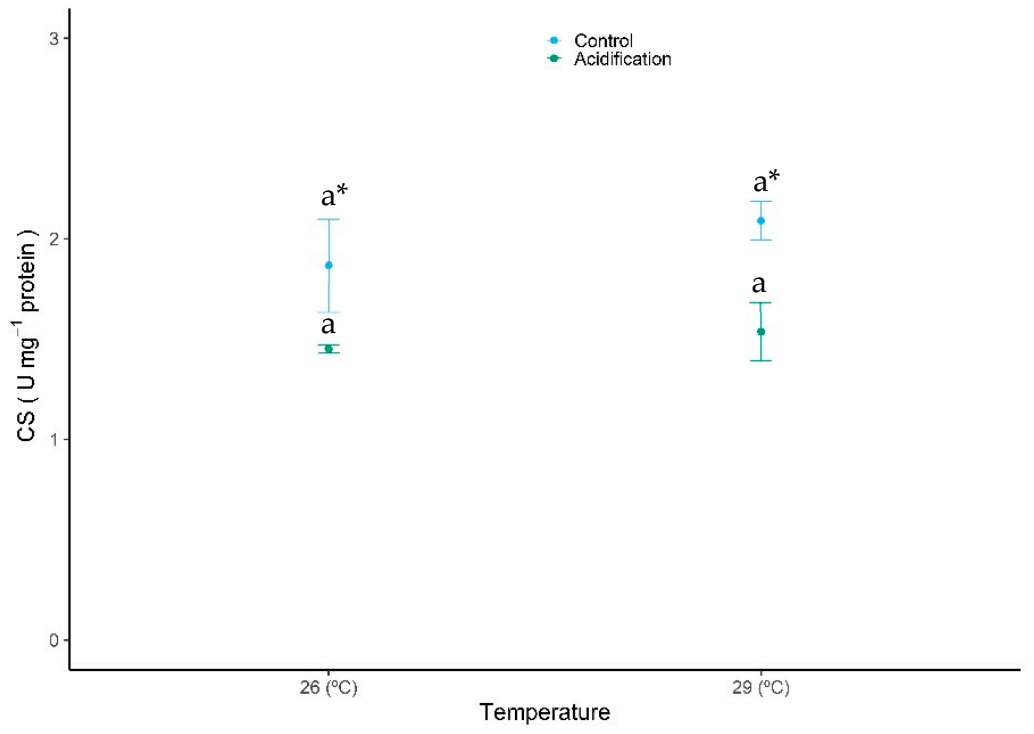

Figure 3. Impact of ocean warming and acidification on the enzyme citrate synthase (CS) activity of Sparus aurata fish larvae. Values are given as mean \pm SD. Different letters $(a, b)$ represent significant differences between the temperature treatments and asterisks $\left(^{*}\right)$ represent significant differences between $\mathrm{CO}_{2}$ e treatments $(p<0.05)$. 
A generally opposite trend was observed for the anaerobic potential-lactate dehydrogenase (LDH) activity - with both temperature and acidification eliciting a significant increase in the activity of LDH (Figure 4, GLM analysis described in Table 1, Gaussian family, $p<0.01$ ). The LDH activity increased with acidification, from $2.04 \pm 0.14$ to $3.75 \pm 0.23 \mathrm{U} \mathrm{mg} \mathrm{protein}^{-1}$ under controlled temperature, and from $2.81 \pm 0.19$ to $4.18 \pm 0.43 \mathrm{U} \mathrm{mg}$ protein ${ }^{-1}$ under warming conditions. No significant interaction was observed between the factors (GLM analysis described in Table 1, Gaussian family, $p>0.05$ ).

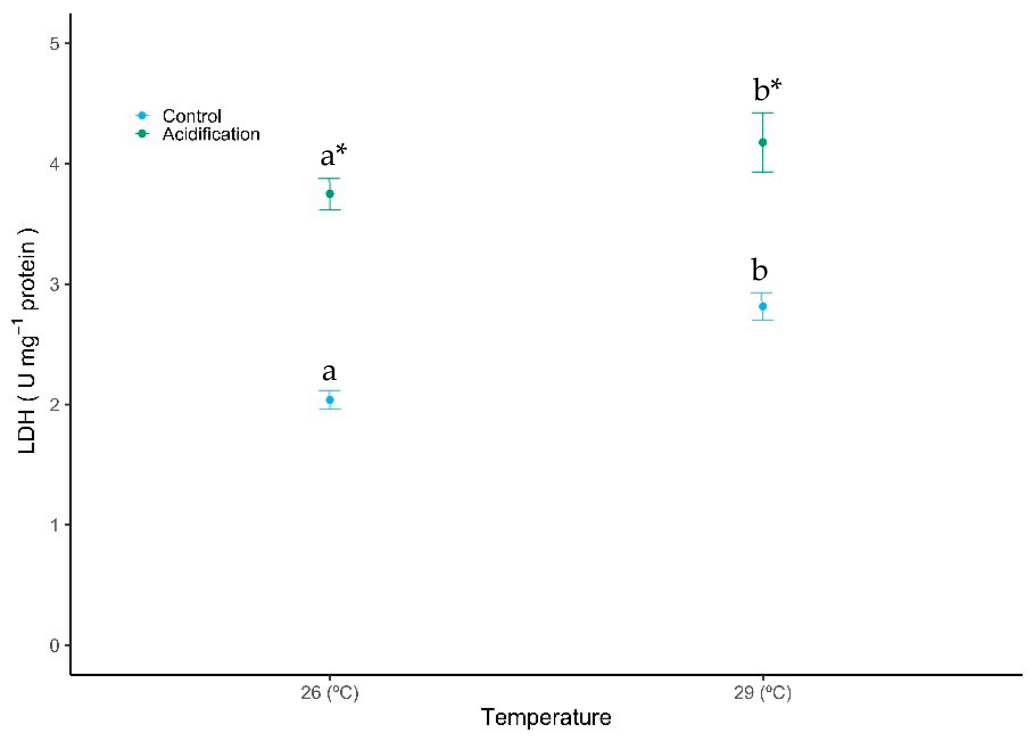

Figure 4. Impact of ocean warming and acidification on the enzyme lactate dehydrogenase (LDH) activity of Sparus aurata fish larvae. Values are given as mean \pm SD. Different letters $(a, b)$ represent significant differences between the temperature treatments and asterisks ${ }^{*}$ ) represent significant differences between $\mathrm{CO}_{2}$ treatments $(p<0.001)$.

The LDH/CS enzyme activity ratio (Table 2) was not significantly affected by temperature, but significantly increased with acidification (GLM analysis described in Table 1, Gaussian family, $p<0.001$ ) by up to $1.47 \%$ (under controlled temperature treatment). The highest value observed was of $2.78 \pm 0.77$ under the combined effect of higher temperature and $\mathrm{CO}_{2}$. Moreover, no significant interaction was observed between the factors (GLM analysis, Gaussian family, $p>0.05$ ). The activity levels of the enzyme associated with lipid metabolism, 3-hydroxyacyl CoA dehydrogenase (HOAD), were also significantly affected by both environmental factors (Figure 5, GLM analysis described in Table 1, Gaussian family, $p<0.05$ ), increasing with warming, but decreasing with acidification from $8.62 \pm 1.32$ to $7.01 \pm 1.36$ to $\mathrm{U} \mathrm{mg}$ protein $^{-1}$ under controlled temperature, and from $10.97 \pm 0.48$ to $8.16 \pm 0.41 \mathrm{U} \mathrm{mg}$ protein ${ }^{-1}$ under warming. No significant interaction was observed between both factors (GLM analysis described in Table 1, Gaussian family, $p>0.05$ ).

Table 2. Ratio of enzyme activity LDH/CS of Sparus aurata larvae under different climate change scenarios. Values are given in mean \pm SD. Different letters $(a, b)$ represent significant differences between all the different treatments $(p<0.05)$.

\begin{tabular}{cc}
\hline Treatments & LDH/CS Ratio \\
\hline $\mathbf{1 8}{ }^{\circ} \mathbf{C}$, pH 8.0 & $1.12 \pm 0.22^{\mathrm{a}}$ \\
$\mathbf{1 8}^{\circ} \mathrm{C}$, pH 7.5 & $2.59 \pm 0.23^{\mathrm{b}}$ \\
$\mathbf{2 2}^{\circ} \mathrm{C}$, pH 8.0 & $1.36 \pm 0.19^{\mathrm{a}}$ \\
$\mathbf{2 2}^{\circ} \mathrm{C}$, pH 7.5 & $2.78 \pm 0.77^{\mathrm{b}}$ \\
\hline
\end{tabular}




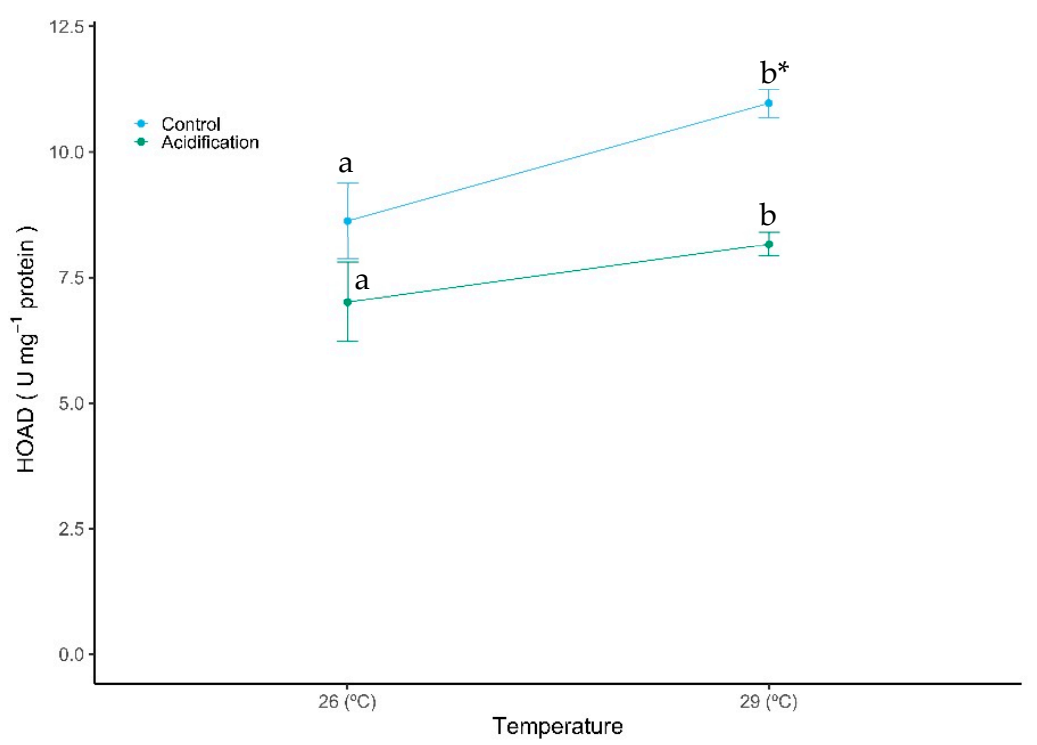

Figure 5. Impact of ocean warming and acidification on the enzyme ß-hydroxyacyl CoA dehydrogenase (HOAD) activity of Sparus aurata fish larvae. Values are given as mean \pm SD. Different letters $(a, b)$ represent significant differences between temperature treatments and asterisk ${ }^{*}$ ) represent significant differences between $\mathrm{CO}_{2}$ treatments $(p<0.05)$.

\section{Discussion}

Fish early life stages are considered to be extremely vulnerable to environmental changes [42]; thus, it is crucial to understand their physiological responses to this changing environment to predict population dynamics and make correct management decisions.

As reported for other species [24,25], the present results also showed that future ocean climate change scenarios affected the oxygen consumption of Sparus aurata larvae. As expected, warming accelerated larval metabolism, increasing both the oxygen consumption and heart rates of seabream larvae. This might increase the energetic extraction from finite yolk reserves and accelerate larval development at the time of yolk sac absorption, limiting the optimal growth of fish larvae and favoring developmental abnormalities [43], as already documented for S. aurata larvae [17]. In contrast, when exposed to high $\mathrm{CO}_{2}$, larvae entered into a more hypometabolic state, presenting lower oxygen consumption and heart rates. Metabolic depression is an important strategy that allows organisms to enhance their tolerance to environmental stressful conditions [34]. However, this strategy is characterized by shutting down expensive processes (e.g., protein synthesis) and is known to limit aerobic scope and reduce animal fitness [34,44], as previously reported for seabream larvae [17]. Alongside with metabolic depression, ocean acidification caused cardiac failure (bradycardia), as already reported for fish adults of other species [45-49], and may result in insufficient blood flow to tissues and limited oxygen supply to sustain cellular aerobic processes [22,42,50]. Cardiac failure as a response to high levels of $\mathrm{CO}_{2}$ has been shown to be species-specific [51,52]; while the cardiac performance of some species significantly decreases with increasing $\mathrm{CO}_{2}$ [47,53-57], other species seem to be more tolerant [48,58-61]. The nature of the variation depends not only on the triggering threshold, but also on the directionality of the response. For those less tolerant species, if their compensatory processes are not effective under high $\mathrm{CO}_{2}$, the trend to lose oxygen transport capacity might persist.

Furthermore, the present results showed that conditions simulating future climate change scenarios induced adjustments of metabolic pathways and of the capacity of oxidative processes in the metabolism of S. aurata larvae. These adjustments led to a significant increase in HOAD and LDH activities with warming, as expected. In contrast, acidification led to the inhibition of the mitochondrial enzymes CS and HOAD, which are key enzymes for the overall aerobic metabolic potential, and to an increase in the anaerobic respiration pathways (indicated by the increase in LDH activity). Metabolic depression and 
decreased aerobic potential under ocean acidification may be a consequence of acid-base regulatory imbalance and hypercapnia-induced extracellular acidosis. A decrease in plasma $\mathrm{pH}$ may decrease hemoglobin- $\mathrm{O}_{2}$ affinity and limit oxygen supply [22,42], thus restricting the aerobic production of energy. Under environmental stress, part of the energy available has to be allocated to withstanding stress and restoring physiological homeostasis, and when the aerobic metabolism by itself is not enough to fulfill the energy demands, the anaerobic pathways of energy production might be activated e.g. $[9,10,26,27,30-33,61,62]$. The higher levels of $\mathrm{LDH}$ and the higher $\mathrm{LDH} / \mathrm{CS}$ ratio in seabream larvae indicated that a transition from aerobic to anaerobic metabolism was required to sustain the higher energetic demands of this species under a future ocean scenario. The activation of anaerobic metabolism under ocean acidification also suggests that fish tissues might become hypoxic [33]. A decrease in aerobic capacity counterbalanced with an increase in the glycolytic potential and heavier dependence of ATP generation via glycolysis after exposure to ocean acidification has been previously reported for S. aurata juveniles and for other fish species [18,27,30-33,62-66]. However, fish responsiveness depends not only on the time taken to acclimate to such environmental variables and life stage, but it might also be species-specific. Contrary to what we here found, some species, such as Scorpaenichthys marmoratus [60] and Trematomus newnesi [66], showed no significant changes in their glycolytic capacity when exposed to high $\mathrm{CO}_{2}$. The increase in glycolytic potential is a common tactic used by organisms to improve tolerance and survival under stressful conditions [34], but it is likely to be unsustainable on longer time-scales. It can be argued that the decrease in aerobic potential might be the result of increased intracellular levels of bicarbonate, due to both increased $p \mathrm{CO}_{2}$ and active $\mathrm{pH}$ buffering by bicarbonate uptake [67]. However, we did not scrutinize here how compensation of extracellular acidosis might occur in early life stages, and how long it will take to regulate and restore extracellular and intracellular $\mathrm{pH}\left(\mathrm{pH}_{\mathrm{e}}\right.$ and $\left.\mathrm{pH}_{\mathrm{i}}\right)$ control levels.

Overall, our findings indicate that seabream larvae may require physiological trade-offs to fully offset the energetic costs of acclimation to climate-change-related stressors. It is important not to forget that although our results gave a glimpse of how this species might react physiologically to climate change, within multiple generations, fish might have the potential for adaptation to the new forthcoming conditions, or even to move in response to such environmental changes. In an era of research devoted to global climate change, it is fundamental to analyze how future ocean conditions are expected to affect species with distinct life strategies and unravel the biochemical and physiological mechanisms that allow species to acclimate and adapt to the predicted changes in the oceans.

\section{Materials and Methods}

\subsection{Larval Rearing}

Sparus aurata eggs were collected in November 2013 in the same conditions as the experiments published previously [17], at the Maresa hatchery (Mariscos de Estero, Huelva, Spain). After collection, eggs were immediately transferred, under controlled conditions, to the aquaculture facilities in Laboratório Marítimo da Guia (Cascais, Portugal), and were acclimated to the different experimental conditions. Eggs and larvae were exposed to four different treatments, a cross-factor design of two temperatures and two $p \mathrm{CO}_{2}$ levels: (1) present day scenario $\left(18{ }^{\circ} \mathrm{C}\right.$-the average sea temperature during the natural spawning season [68,69], $\mathrm{pH}=8.0, p \mathrm{CO}_{2} \approx 340 \mu \mathrm{atm}$ ); (2) warming scenario $\left(22^{\circ} \mathrm{C}, \mathrm{pH}=8.0, p \mathrm{CO}_{2} \approx 340 \mu \mathrm{atm}\right)$ simulating future sSST warming scenario for the western coast of Portugal $\left(+4{ }^{\circ} \mathrm{C}\right.$ above average sSST [70]); (3) high $\mathrm{CO}_{2}$-acidification $\left(18^{\circ} \mathrm{C}, \mathrm{pH}=7.5, \Delta \mathrm{pH}=0.5\right.$, $\left.p \mathrm{CO}_{2} \approx 1500 \mu \mathrm{atm}\right)$ simulating predicted scenario for 2100 [3]; and (4) warming + high $\mathrm{CO}_{2}\left(22^{\circ} \mathrm{C}\right.$, $\left.\mathrm{pH}=7.5, \Delta \mathrm{pH}=0.5, p \mathrm{CO}_{2} \approx 1500 \mu \mathrm{atm}\right)$. This study was approved by the Portuguese National Science Foundation (FCT) and the Ethical Committee of the Portuguese General Veterinarian Directorate (ref: PTCD/BIA-BMA/28647/2017). Eggs were reared in 12 independent recirculating systems (three per treatment), each comprising a $19 \mathrm{~L}$ cylindrical rearing tank connected to a $100 \mathrm{~L}$ sump. To ensure an accurate water temperature in each experimental treatment, rearing tanks were placed inside $400 \mathrm{~L}$ 
water bath tanks. Temperature conditions were kept stable via seawater chiller systems, and $\mathrm{pH}$ levels were automatically adjusted by solenoid valves controlled by a Profilux system connected to individual $\mathrm{pH}$ probes (SCHOTT Instruments, Mainz, Germany). $\mathrm{pH}$ adjustments were guaranteed by the injection of a certified $\mathrm{CO}_{2}$ gas mixture via air stones or by aerating the water with $\mathrm{CO}_{2}$-filtered air. In addition, salinity (kept at $\sim 35$ ), temperature, and $\mathrm{pH}$ levels were manually monitored daily using a multiparameter portable meter. The photoperiod throughout the experiment was set at $14 \mathrm{~L}: 10 \mathrm{D}$. Water quality was ensured during the experiment through the use of mechanical, physical and biological filters, as well by UV sterilization. Ammonia and nitrites were monitored regularly and maintained below detectable levels. Total alkalinity was measured according to Reference [71]. The seawater carbonate chemistry (see Table 3) was calculated using the CO2SYS software (2.1, Carbon Dioxide Information Analysis Center, Oak Ridge, Tennessee, 2012Oa) [72].

Table 3. Seawater carbonate chemistry data for Sparus aurata larvae under different climate change scenarios. Total carbon $\left(\mathrm{C}_{\mathrm{T}}\right)$, carbon dioxide partial pressure $\left(p \mathrm{CO}_{2}\right)$, bicarbonate concentration $\left(\mathrm{HCO}_{3}{ }^{-}\right)$, and aragonite saturation state of seawater $\left(\Omega_{\mathrm{arag}}\right)$ were calculated with CO2SYS using salinity, temperature, $\mathrm{pH}$, and total alkalinity $\left(\mathrm{A}_{\mathrm{T}}\right)$. Values are given as mean $\pm \mathrm{SD}$.

\begin{tabular}{|c|c|c|c|c|c|c|}
\hline $\begin{array}{c}\text { Temperature } \\
\left({ }^{\circ} \mathrm{C}\right)\end{array}$ & $\begin{array}{l}\text { pH (Total } \\
\text { Scale) }\end{array}$ & $\begin{array}{c}\mathbf{A}_{\mathrm{T}} \\
\left(\mu \mathrm{mol} \mathrm{kg} \mathrm{kg}^{-1} \mathrm{SW}\right)\end{array}$ & $\begin{array}{c}\mathrm{C}_{\mathrm{T}}\left(\mu \mathrm{mol} / \mathrm{kg}^{-1}\right. \\
\mathrm{SW})\end{array}$ & 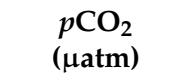 & $\begin{array}{c}\mathrm{HCO}_{3}^{-} \\
\left(\mu \mathrm{mol} \mathrm{kg}{ }^{-1}\right)\end{array}$ & $\Omega_{\text {arag }}$ \\
\hline $18.4 \pm 0.3$ & $8.09 \pm 0.07$ & $2331.7 \pm 67.0$ & $2055.2 \pm 60.5$ & $342.3 \pm 73.7$ & $1836.2 \pm 70.2$ & $3.19 \pm 0.56$ \\
\hline $18.2 \pm 0.3$ & $7.53 \pm 0.04$ & $2318.6 \pm 50.7$ & $2284.0 \pm 57.0$ & $1484.7 \pm 91.0$ & $2169.1 \pm 54.2$ & $0.97 \pm 0.08$ \\
\hline $22.3 \pm 0.3$ & $8.09 \pm 0.07$ & $2308.3 \pm 78.8$ & $1970.5 \pm 80.2$ & $337.0 \pm 73.4$ & $1736.9 \pm 98.7$ & $3.49 \pm 0.49$ \\
\hline $22.1 \pm 0.5$ & $7.53 \pm 0.04$ & $2321.0 \pm 93.3$ & $2292.2 \pm 83.2$ & $1473.0 \pm 92.0$ & $2137.0 \pm 99.5$ & $1.16 \pm 0.10$ \\
\hline
\end{tabular}

After hatching, within the same experimental treatments of egg incubation, seabream larvae were randomly distributed at a density of 70 larvae $\mathrm{L}^{-1}$. The feeding schedule was based on larval development under each set of experimental conditions and adapted from reference [73], where larvae were fed on rotifers (B. plicatilis) between approximately 2 and $15 \mathrm{dph}$, and on Artemia nauplii from 10 to $15 \mathrm{dph}$. At the end of each day, prey availability in each experimental replicate was checked to maintain prey density and ensure that this was never a limiting factor.

Larvae were collected at $15 \mathrm{dph}$, and after collection were immediately placed in liquid nitrogen and then stored at $-80^{\circ} \mathrm{C}$ for posterior enzymatic analyses.

\subsection{Oxygen Consumption and Routine Heart Rates}

Nine 15 dph larvae per treatment were individually incubated in sealed, water-jacketed respirometry chambers (RC300 Respiration Cell, Strathkelvin Instruments Limited, Motherwell, UK), filled with water from the respective treatment. Water volumes were adjusted to larval size in order to allow routine activity and to minimize larval stress. Chambers were immersed in Lauda water baths (Lauda-Königshofen, Germany) to control temperature. Oxygen concentrations were recorded, according to reference [16], with Clark-type $\mathrm{O}_{2}$ electrodes connected to a multi-channel oxygen interface (Model 928, Strathkelvin Instruments Limited, Motherwell, UK). Blanks were run to correct for possible bacterial respiratory activity. After acclimation to the chambers and assuring that larvae were not under stress, respiratory runs lasted $6 \mathrm{~h}$.

Routine heart rates were measured for 12 larvae per treatment. Larvae were individually placed in sealed, water-jacketed respirometry chambers filled with water from the respective treatment and measurements were taken under a stereoscopic microscope (Leica S6D, Leica Microsystems, Wetzlar, Germany) after ensuring that they were not under stress. Routine heart rates were defined as the number of heart beats per unit of time when larvae were motionless. 


\subsection{Enzyme Activity}

Homogenates were prepared in triplicate using $100 \mathrm{mg}$ wet tissue of pooled larvae from each replicate of each treatment, comprising a total of three replicates per treatment. Frozen samples were homogenized in a buffer containing $150 \mathrm{mM}$ imidazole and $1 \mathrm{mM}$ EDTA at pH 7.4 in a glass Potter-Elvehjem tissue grinder (Kartell, Italy) kept on ice. Homogenates were then centrifuged at $10,000 \times g$ for $10 \mathrm{~min}$ at $4{ }^{\circ} \mathrm{C}$.

Maximum activity levels of CS, LDH, and HOAD were determined according to reference [74] and measured using a Shimadzu UV-1800 spectrophotometer (Shimadzu Scientific Instruments, Kyoto, Japan). CS activity was determined based on the reaction of acetyl CoA with DTNB [5.5 V dithio-bis (2-nitrobenzoic acid); extinction coefficient of $13,600 \mathrm{M}^{-1} \mathrm{~cm}^{-1}$ ]. CS activity was assayed in a buffer containing $0.25 \mathrm{mM}$ DTNB, $75 \mathrm{mM}$ Trisbase, and $0.4 \mathrm{mM}$ acetyl CoA at $\mathrm{pH}$ 8.0. The reactions were initiated by adding $0.5 \mathrm{mM}$ oxaloacetate. Changes in absorbance were measured at $412 \mathrm{~nm}$ over $1 \mathrm{~min}$ at $20^{\circ} \mathrm{C}$. LDH and HOAD enzyme activities were measured following the oxidation of NADH (extinction coefficient of $6220 \mathrm{M}^{-1} \mathrm{~cm}^{-1}$ ). LDH activity was assayed using $1 \mathrm{mM}$ pyruvate as substrate in a buffer containing $0.15 \mathrm{mM} \mathrm{NADH}, 50 \mathrm{mM}$ imidazole, and $1 \mathrm{mM}$ EDTA at $\mathrm{pH}$ 7.4. HOAD activity was assayed using $0.1 \mathrm{mM}$ acetoacetyl CoA as substrate in a buffer containing $0.15 \mathrm{mM}$ NADH, $1 \mathrm{mM}$ EDTA, and $50 \mathrm{mM}$ imidazole at $\mathrm{pH}$ 7.5. Changes in absorbance were measured at $340 \mathrm{~nm}$ for both enzymes.

All enzymatic activities were measured in triplicate and expressed as the amount of substrate converted to product per minute in relation to the total protein content, which was determined according to Reference [75]. The LDH/CS enzyme activity ratio was then determined in order to understand which type of metabolism is prevalent.

\subsection{Statistical Analysis}

Statistical analyses of the defined variables were performed with RStudio Software (1.2.5001, RStudio, Inc, Boston, MA, USA, 2019) [76]. All generalized linear models (GLM) were performed with temperature and $\mathrm{pH}$ as factor. For all the variables analyzed, replicates were first included in generalized linear mixed models (GLMM) as a random effect, to account for potential variability in the experimental design. However, random effects were not kept in the models because the amount of variation they explained was less than $5 \%$. The best models for each output were selected according to the calculation of Akaike information criterion (AIC) and used for inference. AIC is a widespread indicator that balances model complexity with model quality of fitness [77]. The distributional family considered was Gamma for oxygen consumption rates and Gaussian (identity link function) for heart rates, $\mathrm{CS}$ activity, $\mathrm{LDH}$ activity, $\mathrm{LDH} / \mathrm{CS}$ ratio, and $\mathrm{HOAD}$ activity.

Author Contributions: M.S.P., F.F. and R.R. designed the experiment; M.S.P. and F.F. performed the experiment; M.S.P., F.F., J.M., P.P.-F. and R.R. analyzed the data; M.S.P. and R.R. wrote the main paper. All authors discussed the results and their implications and commented on the manuscript at all stages. All authors have read and agreed to the published version of the manuscript.

Funding: The Portuguese Foundation for Science and Technology (FCT) supported this study through a post-doctoral grant to M.S.P. (SFRH/BPD/117533/2016), to F.F. (SFRH/BPD/79038/2011), and project grant to M.S.P. (PTCD/BIA-BMA/28647/2017, LISBOA-01-0145-FEDER-028647).

Acknowledgments: Authors would like to express their gratitude to Mário Diniz and to Maresa (Mariscos de Estero, Spain) for supplying fish eggs. We also thank to LusoReef, Oceanário de Lisboa and Aquário Vasco da Gama for supplying rotifers and microalgae.

Conflicts of Interest: The authors declare no conflicts of interest.

\section{References}

1. Caldeira, K.; Wickett, M.E. Ocean model predictions of chemistry changes from carbon dioxide emissions to the atmosphere and ocean. J. Geophys. Res. 2005, 110. [CrossRef] 
2. Pörtner, H.; Karl, D.; Boyd, P.; Cheung, W.; Lluch-Cota, S.; Nojiri, Y.; Schmidt, D.; Zavialov, P. Climate Change 2014: Impacts, Adaptation, and Vulnerability Part A: Global and Sectoral Aspects. Contribution of Working Group II to the Fifth Assessment Report of the Intergovernmental Panel on Climate Change. In Ocean Systems; Field, C., Barros, V., Dokken, D., Mach, K., Mastrandrea, M., Bilir, T., Chatterjee, M., Ebi, K., Estrada, Y., Genova, R., et al., Eds.; Cambridge University Press: Cambridge, UK; New York, NY, USA, 2014; pp. 411-484.

3. IPCC. Climate Change 2013: The Physical Science Basis; Contribution of Working Group I to the Fifth Assessment Report of the Intergovernmental Panel on Climate Change; Cambridge University Press: Cambridge, UK; New York, NY, USA, 2013.

4. Collins, M.; Knutti, R.; Arblaster, J.; Dufresne, J.L.; Fichefet, T.; Friedlingstein, P.; Gao, X.; Gutowski, W.; Johns, T.; Krinner, G.; et al. Long-Term Climate Change: Projections, Commitments and Irreversibility. In Climate Change 2013: the Physical Science Basis; Contribution of Working Group I to the Fifth Assessment Report of the Intergovernmental Panel on Climate Change; Cambridge University Press: Cambridge, UK; New York, NY, USA, 2013.

5. Fabry, V.J.; Seibel, B.A.; Feely, R.A.; Orr, J.C. Impacts of ocean acidification on marine fauna and ecosystem processes. ICES Mar. Res. 2008, 65, 414-432. [CrossRef]

6. Hofmann, G.E.; Todgham, A.E. Living in the now: Physiological mechanisms to tolerarte a rapidly changing environment. Ann. Rev. Physiol. 2010, 27, 127-145. [CrossRef] [PubMed]

7. Hofmann, G.E.; Barry, J.P.; Edmunds, P.J.; Gates, R.D.; Hutchuns, D.A.; Klinger, K.; Sewell, M.A. The effects of ocean acidification in polar, tropical and temperate marine calcifying organisms: An organism to ecosystem perspective. Ann. Rev. Ecol. Evol. Syst. 2010, 41, 127-147. [CrossRef]

8. Melzner, F.; Gutowska, M.A.; Langenbuch, M.; Dupont, S.; Lucassen, M.; Thorndyke, M.C.; Bleich, M.; Portner, H.O. Physiological basis for high CO2 tolerance in marine ectothermic animals: Pre-adaptation through lifestyle and ontogeny? Biogeosciences 2009, 6, 2313-2331. [CrossRef]

9. Pörtner, H.; Farrell, A. Physiology and Climate Change. Science 2008, 322, 690-692. [CrossRef]

10. Pörtner, H.O. Ecosystem effects of ocean acidification in times of ocean warming: A physiologist's view. Mar. Ecol. Prog. 2008, 373, 203-217. [CrossRef]

11. Shepherd, J.G.; Cushing, D.H. A mechanism for density-dependent survival of larval fish as the basis of a stock-recruitment relationship. ICES J. Mar. Res. 1980, 39, 160-167. [CrossRef]

12. Houde, E.D. Fish early life dynamics and recruitment variability. Am. Fish. Soc. Symp. 1987, 2, 17-29.

13. Frommel, A.; Maneja, F.; Lowe, D.; Pascoe, C.; Geffen, A.; Folkvord, A.; Piatkowski, U.; Clemmensen, C. Organ damage in Atlantic herring larvae as a result of ocean acidification. Ecol. Appl. 2014, 24, 1131-1143. [CrossRef]

14. Frommel, A.Y.; Maneja, R.; Lowe, D.; Malzahn, A.M.; Geffen, A.J.; Folkvord, A.; Piatkowski, U.; Reusch, T.B.U.; Clemmesen, C. Severe tissue damage in Atlantic cod larvae under increasing ocean acidification. Nat. Clim. Chang. 2012, 2, 42-46. [CrossRef]

15. Munday, P.L.; McCormick, M.I.; Nilsson, G.E. Impact of global warming and rising $\mathrm{CO}_{2}$ levels on coral reef fishes: What hope for the future? J. Exp. Biol. 2012, 215, 3865-3873. [CrossRef] [PubMed]

16. Pimentel, M.S.; Faleiro, F.; Dionísio, G.; Repolho, T.; Pousão-Ferreira, P.; Machado, J.; Rosa, R. Defective skeletogenesis and oversized otoliths in fish early stages in a changing ocean. J. Exp. Biol. 2014, 217, 2062-2070. [CrossRef] [PubMed]

17. Pimentel, M.S.; Faleiro, F.; Marques, T.; Bispo, R.; Dionísio, G.; Faria, A.M.; Machado, J.; Peck, M.A.; Pörtner, H.O.; Pousão-Ferreira, P.; et al. Foraging behaviour, swimming performance and malformations of early stages of commercially important fishes under ocean acidification and warming. Clim. Chang. 2016, 137, 495-509. [CrossRef]

18. Tseng, Y.C.; Hu, M.U.; Stumpp, M.; Lin, L.Y.; Melzner, F.; Hwang, P.P. $\mathrm{CO}_{2}$-driven seawater acidification differentially affects development and molecular plasticity along life history of fish (Oryzias latipes). Comp. Biochem. Physiol. Part A 2013, 165, 119-130. [CrossRef]

19. Pimentel, M.S.; Faleiro, F.; Diniz, M.; Machado, M.; Pousão-Ferreira, P.; Peck, M.; Pörtner, H.O.; Rosa, R. Oxidative stress and digestive enzyme activity of flatfish larvae in a changing ocean. PLOS ONE 2015, 10, e0134082. [CrossRef]

20. Morris, R.; Taylor, E.W.; Brown, D.J.A.; Brown, J.A. Acid Toxicity and Aquatic Animals; Society for Experimental Biology Seminar Series; Cambridge University Pres: Cambridge, UK, 1989. 
21. Sayer, M.D.J.; Reader, J.P.; Dalziel, T.R.K. Fresh-water acidification-Effects on the early-life stages of fish. Rev. Fish Biol. Fish. 1993, 3, 298. [CrossRef]

22. Pörtner, H.O.; Langenbuch, M.; Reipschlager, A. Biological impact of elevated ocean $\mathrm{CO}_{2}$ concentrations: Lessons from animal physiology and earth history. J. Ocean. 2004, 60, 705-718. [CrossRef]

23. Munday, P.L.; Donelson, J.M.; Dixson, D.L.; Endo, G.K. Effects of ocean acidification on the early life history of a tropical marine fish. Proc. R. Soc. B Biol. Sci. 2009, 276, 3275-3283. [CrossRef]

24. Rummer, J.L.; Stecyk, J.A.; Couturier, C.S.; Watson, S.A.; Nilsson, G.E.; Munday, P.L. Elevated $\mathrm{CO}_{2}$ enhances aerobic scope of a coral reef fish. Conserv. Physiol. 2013, 1, cot023. [CrossRef]

25. Couturier, C.S.; Stecyk, J.A.W.; Rummer, J.L.; Munday, P.L.; Nilsson, G.E. Species-specific effects of near-future $\mathrm{CO}_{2}$ on the respiratory performance of two tropical prey fish and their predator. Comp. Biochem. Phys. A 2013, 166, 482-489. [CrossRef] [PubMed]

26. Campos, D.F.; Jesus, T.F.; Kochhann, D.; Heinrichs-Caldas, W.; Coelho, M.M.; Almeida-Val, V.M.F. Metabolic rate and thermal tolerance in two congeneric Amazon fishes: Paracheirodon axelrodi Schultz, 1956 and Paracheirodon simulans Géry, 1963 (Characidae). Hydrobiologia 2017, 789, 133-142. [CrossRef]

27. Jesus, T.F.; Rosa, I.C.; Repolho, T.; Lopes, A.R.; Pimentel, M.S.; Almeida-Val, V.M.F.; Coelho, M.M.; Rosa, R. Different ecophysiological responses of freshwater fish to warming and acidification. Comp. Biochem. Physiol. Part A Mol. Integr. Physiol. 2018, 216, 34-41. [CrossRef] [PubMed]

28. Pörtner, H. Oxygen- and capacity-limitation of thermal tolerance: A matrix for integrating climate-related stressor effects in marine ecosystems. J. Exp. Biol. 2010, 213, 881-893. [CrossRef] [PubMed]

29. Pörtner, H. Integrating climate-related stressor effects on marine organisms: Unifying principles linking molecule to ecosystem-level changes. Mar. Ecol. Prog. Ser. 2012, 470, 273-290. [CrossRef]

30. Rosa, R.; Ricardo Paula, J.; Sampaio, E.; Pimentel, M.; Lopes, A.R.; Baptista, M.; Guerreiro, M.; Santos, C.; Campos, D.; Almeida-Val, V.M.F.; et al. Neuro-oxidative damage and aerobic potential loss of sharks under elevated CO2 and warming. Mar. Biol. 2016, 163, 119. [CrossRef]

31. Strobel, A.E.; Leo, E.; Pörtner, H.O.; Mark, F.C. Elevated temperature and $\mathrm{PCO}_{2}$ shift metabolic pathways in differentially oxidative tissues of Notothenia rossii. Comp. Biochem. Physiol. B Biochem. Mol. Biol. 2013, 166, 48-57. [CrossRef]

32. Feidantsis, K.; Portner, H.O.; Antonopoulou, E.; Michaelidis, B. Synergistic effects of acute warming and low $\mathrm{pH}$ on cellular stress responses of the gilthead seabrea Sparus aurata. J. Comp. Physiol. B 2015, 185, 185-205. [CrossRef]

33. Michaelidis, B.; Spring, A.; Pörtner, H.O. Effects of long-term acclimation to environmental hypercapnia on extracellular acid-base status and metabolic capacity in Mediterranean fish Sparus aurata. Mar. Biol. 2007, 150, 1417-1429. [CrossRef]

34. Hochachka, P.W.; Somero, G.N. Biochemical Adaptation: Mechanisms and Process in Physiological Evolution; Oxford University Press: Oxford, UK, 2002.

35. Bennet, A.F. Activity metabolism of the lower vertebrates. Ann. Rev. Physiol. 1979, 400, 447-469. [CrossRef]

36. McClelland, G.B.; Craig, P.M.; Dhekney, K.; Dipardo, S. Temperature- and exerciseinduced gene expression and metabolic enzyme changes in skeletal muscle of adult zebrafish (Danio rerio). J. Physiol. 2006, 577, 739-751. [CrossRef] [PubMed]

37. Somero, G.; Childress, J. A violation of the metabolism-size scaling paradigm-Activities of glycolytic-enzymes in muscle increase in larger-size fish. Physiol. Zool. 1980, 53, 322-337. [CrossRef]

38. Powers, S.K.; Demirel, H.A.; Coombes, J.S.; Fletcher, L.; Calliaud, C.; Vrabas, I.; Prezant, D. Myosin phenotype and bioenergetic characteristics of rat respiratory muscles. Med. Sci. Sports Exerc. 1977, 29, 1573-1579. [CrossRef] [PubMed]

39. Newsholme, E.; Leech, A. Biochemistry for the Medical Sciences; Wiley and Sons: New York, NY, USA, 1988.

40. Hochachka, P.W.; Stanley, C.; Merkt, J.; Sumar-Kalinowski, J. Metabolic meaning of elevated levels of oxidative enzymes in high altitude adapted animals: An interpretive hypothesis. Respir. Physiol. 1983, 52, 303-313. [CrossRef]

41. Bauchot, M.L.; Hureau, J.C. Sparidae. In Checklist of the Fishes of the Eastern Tropical Atlantic (CLOFETA); Quero, J.C., Hureau, J.C., Karrer, C., Post, A., Saldanha, L., Eds.; JNICT: Lisbon, Portugal; SEI: Paris, France; UNESCO: Paris, France, 1990; Volume 2, pp. 790-812. 
42. Pörtner, H.O.; Langenbuch, M.; Michaelidis, B. Synergistic effects of temperature extremes, hypoxia, and increases in $\mathrm{CO}_{2}$ on marine animals: From Earth history to global change. J. Geophys. Res. Oceans 2005, 110. [CrossRef]

43. Perrichon, P.; Pasparakis, C.; Mager, E.M.; Stieglitz, J.D.; Benetti, D.D.; Grosell, M.; Burggren, W.W. Morphology and cardiac physiology are differentially affected by temperature in developing larvae of the marine fish mahi-mahi (Coryphaena hippurus). Biol. Open 2017, 6, 800-809. [CrossRef]

44. Storey, K.B.; Storey, J.M. Oxygen limitation and metabolic ratedepression. In Functional Metabolism. Regulation and Adaptation; Storey, K.B., Ed.; Wiley: Hobocken, NJ, USA, 2004; pp. 415-442.

45. Perry, S.F.; Reid, S.G. Cardiorespiratory adjustments during hypercarbia in rainbow trout Oncorhynchus mykiss are initiated by external $\mathrm{CO}_{2}$ receptors on the first gill arch. J. Exp. Biol. 2002, 205 Pt 21, 3357-3365.

46. Ishimatsu, A.; Kikkawa, T.; Hayashi, M.; Lee, K.S.; Kita, J. Effects of CO2 on marine fish: Larvae and adults. J. Oceanogr. 2004, 60, 731-741. [CrossRef]

47. Lee, K.S.; Kita, J.; Ishimatsu, A. Effects of lethal levels of environmental hypercapnia on cardiovascular and blood-gas status in yellowtail Seriola quinqueradiata. Zool. Sci. 2003, 20,417-422. [CrossRef]

48. Crocker, E.C.; Cech, J.J.J. Effects of hypercapnia on bloodgas and acid-base status in the white sturgeon, Acipenser transmontanus. J. Comp. Physiol. 1998, 168B, 50-60. [CrossRef]

49. Reid, S.G.; Sundin, L.; Kalinin, A.L.; Rantin, F.T.; Milsom, W.K. Cardiovascular and respiratory reflexes in the tropical fish, traira (Hoplias malabaricus): $\mathrm{CO}_{2} / \mathrm{pH}$ chemoresponses. Respir. Physiol. 2000, 120, 47-59. [CrossRef]

50. Farrell, A.P.; Eliason, E.J.; Sandblom, E.; Clark, T.D. Fish cardiorespiratory physiology in an era of climate change. Can. J. Zool. 2009, 87, 835-851. [CrossRef]

51. Gilmour, K.M.; Perry, S.F. Branchial chemoreceptor regulation of cardiorespiratory function. In Fish Physiology; Hara, T., Zielinksi, B., Eds.; Elsevier: San Diego, CA, USA, 2007; pp. 97-151.

52. Perry, S.F.; Abdallah, S. Mechanisms and consequences of carbon dioxide sensing in fish. Respir. Physiol. Neurobiol. 2012, 184, 309-315. [CrossRef] [PubMed]

53. Smart, G.R.; Knox, D.; Harrison, J.G.; Ralph, J.A.; Richards, R.H.; Cowey, C.B. Nephrocalcinosis in rainbow trout Salmo gairdneri Richardson; the effect of exposure to elevated $\mathrm{CO}_{2}$ concentration. J. Fish Dis. 1979, 2, 279-289. [CrossRef]

54. Hayashi, M.; Kita, J.; Ishimatsu, A. Acid-base responses to lethal aquatic hypercapnia in three marine fishes. Mar. Biol. 2004, 144, 153-160. [CrossRef]

55. Perry, S.F.; Fritsche, R.; Hoagland, T.M.; Duff, D.W.; Olson, K.R. The control of blood pressure during external hypercapnia in the rainbow trout (Oncorhynchus mykiss). J. Exp. Biol. 1999, 202, 2177-2190.

56. McKendry, J.E.; Milsom, W.K.; Perry, S.F.; Steffensen, J.F. Branchial $\mathrm{CO}_{2}$ receptors and cardiorespiratory adjustments during hypercarbia in Pacific spiny dogfish (Squalus acanthias). J. Exp. Biol. 2001, 204, 1519-1527.

57. Sundin, L.; Reid, S.G.; Rantin, F.T.; Milsom, W.K. Branchial receptors and cardiorespiratory reflexes in the neotropical fish, Tambaqui (Colossoma macropomum). J. Exp. Biol. 2000, 203, 1225-1239.

58. Fivelstad, S.; Olsen, A.B.; Kluften, H.; Ski, H.; Stefansson, S. Effects of carbon dioxide on Atlantic salmon (Salmo salar L.) smolts, at constant pH in bicarbonate rich freshwater. Aquaculture 1999, 178, 171-187. [CrossRef]

59. Blancheton, J.P. Developments in recirculation systems for Mediterranean fish species. Aquac. Eng. 2000, 22, 17-31. [CrossRef]

60. Davis, B.E.; Miller, N.A.; Flynn, E.E.; Todgham, A.E. Juvenile Antarctic rockcod (Trematomus bernacchii) are physiologically robust to $\mathrm{CO}_{2}$-acidified seawater. J. Exp. Biol. 2016, 219, 1203-1213. [CrossRef] [PubMed]

61. Davis, B.E.; Flynn, E.E.; Miller, N.A.; Nelson, F.A.; Fangue, N.A.; Todgham, A. Antarctic emerald rockcod have the capacity to compensate for warming when uncoupled from $\mathrm{CO}_{2}$-acidification. Glob. Chang. Biol 2018, 24, e655-e670. [CrossRef] [PubMed]

62. Strobel, A.; Bennecke, S.; Leom, E.; Mintenbeck, K.; Pörtner, H.O.; Mark, F.C. Metabolic shifts in the Antarctic fish Notothenia rossii in response to rising temperature and $\mathrm{pCO}_{2}$. Front. Zool. 2012, 9, 28. [CrossRef] [PubMed]

63. Davis, B.E.; Komoroske, L.M.; Hansen, M.; Poletto, J.B.; Perry, E.N.; Miller, N.A.; Ehlman, S.M.; Wheeler, S.G.; Sih, A.; Todgham, A.E.; et al. Juvenile rockfish show resilience to $\mathrm{CO}_{2}$-acidification and hypoxia across multiple biological scales. Conserv. Physiol. 2018, 6, coy038. [CrossRef] 
64. Strobel, A.; Graeve, M.; Pörtner, H.O.; Mark, F.C. Mitochondrial acclimation capacities to ocean warming and acidification are limited in the Antarctic nototheniid fish, Notothenia rossii and Lepidonotothen squamifrons. PLOS ONE 2013, 8, e68865. [CrossRef]

65. Flynn, E.E.; Bjelde, B.E.; Miller, N.A.; Todgham, A.E. Ocean acidification exerts negative effects during warming conditions in a developing Antarctic fish. Conserv. Physiol. 2015, 3, cov033. [CrossRef]

66. Enzor, L.A.; Hunter, E.M.; Place, S.P. The effects of elevated temperature and ocean acidification on the metabolic pathways of notothenioid fish. Conserv. Physiol. 2017, 5, cox019. [CrossRef]

67. Brauner, C.J.; Baker, D.W. Patterns of Acid-Base Regulation during Exposure to Hypercarbia in Fishes. In Cardio-Respiratory Control in Vertebrates: Comparative and Evolutionary Aspects; Glass, M.L., Wood, S.C., Eds.; Springer: Berlin, Germany, 2009; pp. 43-63.

68. Arias, A. Crecimiento, regimen alimentario y reproducción de la dorada (Sparus aurata L.) y del robalo (Dicentrarchus labrax L.) en los esteros de Cadiz. Investig. Pesq. 1980, 44, 59-83.

69. Kissil, G.; Lupatsch, I.; Elizur, A.; Zohar, Y. Long photoperiod delayed spawning and increased somatic growth in gilthead seabream (Sparus aurata). Aquaculture 2001, 200, 363-379. [CrossRef]

70. Meehl, G.A.; Stocker, T.F.; Collins, W.D.; Firedlingstein, P.; Gaye, A.T.; Gregory, J.M.; Kitoh, A.; Knutti, R.; Murphy, J.M.; Noda, E.A. Climate Change 2007: The Physical Science Basis; Contribution of working group I to the Fourth Assessment Report of the Intergovernmental Panel on Climate Change; Cambridge University Press: Cambridge, UK, 2007.

71. Sarazin, G.; Michard, G.; Prevot, F. A rapid and accurate spectroscopic method for alkalinity measurements in sea water samples. Water Res. 1999, 33, 290-294. [CrossRef]

72. Lewis, E.; Wallace, D.W.R. $\mathrm{CO}_{2} \mathrm{SYS}$-Program Developed for the $\mathrm{CO}_{2}$ System Calculations; Report ORNL/CDIAC-105; Carbon Dioxide Inf Anal Center, Oak Ridge Natl. Lab.: Oak Ridge, TN, USA, 1998.

73. Fernández, I.; Hontoria, F.; Ortiz-Delgado, J.B.; Kotzamanis, Y.; Estevez, A.; Zambonino-Infante, J.L.; Gisbert, E. Larval performance and skeletal deformities in farmed gilthead sea bream (Sparus aurata) fed with graded levels of vitamin A enriched rotifers (Brachionus plicatilis). Aquaculture 2008, 283, 102-115. [CrossRef]

74. Driedzic, W.R.; deAlmeidaVal, V.M.F. Enzymes of cardiac energy metabolism in Amazonian teleosts and the fresh-water stingray (Potamotrygon hystrix). J. Exp. Zool. 1996, 274, 327-333. [CrossRef]

75. Bradford, M.M. Rapid and sensitive method for quantitation of microgram quantities of protein utilizing principle of protein-dye binding. Anal. Biochem. 1976, 72, 248-254. [CrossRef]

76. R Development Core Team. R: A Language and Environment for Statistical Computing. 2019. Available online: www.R-project.org (accessed on 10 February 2019).

77. Quinn, G.P.; Keough, M.J. Experimental Design and Data Analysis for Biologists; Cambridge University Press: Cambridge, UK, 2002. 